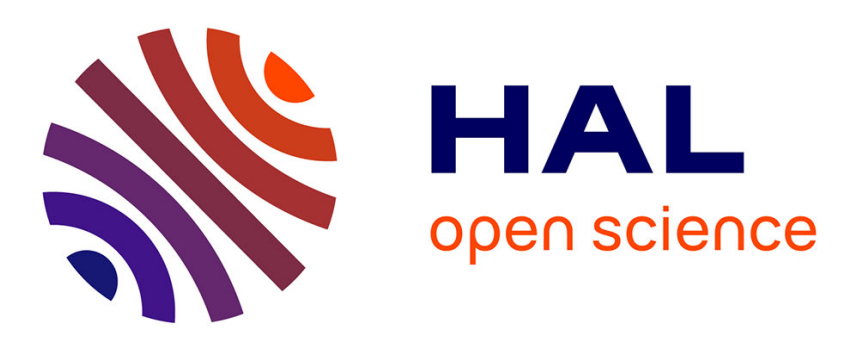

\title{
The composition of sedimentary organic matter in relation to the dynamic features of the mangrove-fringed coast in French Guiana.
}

Cyril Marchand, Elisabeth Lallier-Vergès, F. Baltzer

\section{- To cite this version:}

Cyril Marchand, Elisabeth Lallier-Vergès, F. Baltzer. The composition of sedimentary organic matter in relation to the dynamic features of the mangrove-fringed coast in French Guiana.. Estuarine, Coastal and Shelf Science, 2003, 56, pp.119-130. 10.1016/S0272-7714(02)00134-8 . hal-00069448

\section{HAL Id: hal-00069448 \\ https://hal-insu.archives-ouvertes.fr/hal-00069448}

Submitted on 8 Aug 2006

HAL is a multi-disciplinary open access archive for the deposit and dissemination of scientific research documents, whether they are published or not. The documents may come from teaching and research institutions in France or abroad, or from public or private research centers.
L'archive ouverte pluridisciplinaire $\mathbf{H A L}$, est destinée au dépôt et à la diffusion de documents scientifiques de niveau recherche, publiés ou non, émanant des établissements d'enseignement et de recherche français ou étrangers, des laboratoires publics ou privés. 


\title{
The composition of sedimentary organic matter in relation to the dynamic features of a mangrove-fringed coast in French Guiana
}

\author{
C. Marchand ${ }^{\mathrm{a}}$, E. Lallier-Vergès ${ }^{\mathrm{a}}$ and F. Baltzer $^{\mathrm{b}}$ \\ ${ }^{a}$ Géosciences, Institut des Sciences de la Terre d'Orléans, Université d'Orléans, UMR 6113 \\ CNRS-UO, 45067, Orléans, France \\ ${ }^{\mathrm{b}}$ Laboratoire d'Hydrogéologie et de Géochimie Isotopique, Université Paris Sud, UMR 8616, \\ 91405, Orsay, France
}

Author Keywords: Mangrove sediments; Organic matter; Rock-Eval analyses; Organic petrography; Redox potential; Avicennia germinans; French Guiana

\begin{abstract}
The sedimentary organic matter content of a series of 2-m-deep cores was examined in relation to the evolution of mangrove forest, on the basis of geochemical analyses and optical observations. Avicennia-dominated forest deposits, developing along the highly dynamic coastline of French Guiana, were collected in five stations based on stage of forest evolution. The sedimentary organic matter in the upper sediment of the youngest mangrove swamp is mainly derived from algal mats with low carbon:nitrogen ratios ( $\mathrm{C}: \mathrm{N}$ ratio, from 6 to 8 ) and typical greyish amorphous organic flakes as observed in optical studies. Indeed, rare young Avicennia trees are present, and effectively, geochemical parameters do not give evidence of a litter made up of higher plant debris, these rare debris being probably exported by the tides. A slight increase with depth in the first decimetres of both total organic carbon (TOC) content and $\mathrm{C}: \mathrm{N}$ ratio results from the development of the radial cable root-system of the pioneer Avicennia germinans. Early diagenetic conditions of this young forest are rather controlled by dominant suboxic processes, as suggested by high Eh values (range, 200-400 mV) and local anoxic processes (occurrence of pyrite) in micro-environments: this is mainly due to the oxygen available by roots and crab bioturbation. The organic content of the senescent mangrove sediment is mainly derived from higher plant debris in the uppermost $30 \mathrm{~cm}$, as indicated by relatively high $\mathrm{C}: \mathrm{N}$ ratios and the predominance of ligno-cellulosic debris. The strong decrease in hydrogen index values results from the degradation of the higher plant debris, losing hydrogen bounds through decay processes. Moderately acidic $\mathrm{pH}$ values, low Ehs and the presence of pyrite framboids point towards the reducing decay processes in surficial layers of the senescent mangrove mediated by sulphate-reducing bacteria. Whatever the stage of evolution of the forest, the geochemical characteristics of the sediment below $30 \mathrm{~cm}$ are those of the shoreface one, with opaque refractory debris derived from the Amazon river detritus discharge. The sediment collected from dead mangrove forests, subsequently recolonized by pioneer mangroves, contains organic markers, which predate recolonization, recording previous phases of erosion and accretion.
\end{abstract}




\section{Introduction}

The coastline of French Guiana is a highly dynamic environment, surprisingly composed of predominantly fine-grained sediment. This muddy coastline results from the huge mud discharge of the river Amazon, partly deflected northwestward by the current of the Guianas. The mudbanks, being eroded on their windward side and accreting on their lee side, move rapidly $\left(1.4 \mathrm{~km} \mathrm{year}^{-1}\right.$ ) along the coast (Allison, Lee, Ogston, \& Aller, 2000). A dense recruitment of mangrove propagules (predominantly Avicennia germinans) follows this phase within months. Subsequently, a mature to senescent mangrove forest develops up to a point, about 30 years later, when the windward end of the mudbank reaches the considered location and the erosion fells the Avicennia trees. Previous erosion episodes have left residual strips of forest, in front of which, new phases of accretion bring sediments on which new similar recruitments take place. The mangrove of different ages were sorted in field into five stages of mangrove evolution according to their structural and biological features (Fromard et al., 1998): pioneer forest, young forest, young mature forest, senescent forest and 'recolonized' cemetery forest.

Mangrove forests are common tropical intertidal ecosystems. They are characterized by a vegetation developing a high capacity for adaptation to the environmental conditions. Notably, A. germinans develops radiating cable roots supporting vertical pneumatophores. Mangrove forests are considered as a very productive area (Odum \& Heald, 1975) with high rates of accumulation of organic carbon ( Huc, 1980). Earlier studies ( Lallier-Vergès, Perrussel, Disnar, \& Baltzer, 1998), carried out in Guadeloupe (French West Indies), where different species are predominant, have exhibited high contents of sedimentary organic matter (total organic carbon (TOC) range, 18-47\%) mainly composed of higher plant debris, which are decayed by microbial activity. However, the dynamic features of the Guiana's coastline and the youthfulness of the resulting forest, under 10 years except for the senescent forest (around 50 years old), may influence the organic content of the sediment, its origin and the early diagenetic conditions.

The decomposition of organic matter in mangrove sediments has been widely studied (Nedwell et al., 1994; Lacerda et al., 1995; Alongi et al., 2000 and Alongi et al., 1999). Relations between decomposition and forest type, water table fluctuation and activity of sulphate-reducing bacteria are known. However, the relationship between the forest evolution and the sedimentary organic content is not well known, and few studies have been performed towards this end ( Alongi, Sasakumar, Tirendi, \& Dixon, 1998). Moreover, few data are available on the origin of the sedimentary organic matter, i.e. the proportion of algae-derived organic matter compared with that derived from higher plants.

To define the relationship between the evolution of this A. germinans-dominated mangrove forest, the organic composition of the sediment and the physico-chemical conditions is the main purpose of this study. Indeed, textural and geochemical properties of the sedimentary organic matter are key parameters not only of the paleoenvironmental and paleoclimatic reconstruction of Quaternary series (i.e. Meyers, 1997 and Meyers and Lallier-Vergès, 1999), but also of ancient sedimentary formations. Therefore, it is necessary to calibrate the so-used sedimentary organic markers through the study of present environments, assumed to encounter organic matter preservation. Our approach is to combine total petrographic and geochemical studies, similar to those conducted on geological formations as deltaic ones, 
which may present fossilized littoral peat-bog systems (i.e. Buillit, Lallier-Vergès, Pradier, \& Nicolas, 2002). This approach allows a direct comparison of the organic content and a confrontation with depositional conditions.

For this study, a series of 2-m-deep cores were collected within mangrove forests at different stages of their evolution, and one additional core was collected in the shoreface sediment as a reference. This work includes organic geochemical data obtained from both Rock-Eval pyrolyser (TOC, HI, oxygen index (OI)) and LECO analyser (C, N, S), such as optical observations and counts. These data are confronted to the physico-chemical parameters measured in the sediment ( $\mathrm{Eh}$ and $\mathrm{pH}$ ) and to the physiognomy of the ecosystems encountered.

\section{Materials and methods}

\subsection{Study sites}

The studied mangrove is situated on the right bank of the Sinnamary river, $50 \mathrm{~km}$ northwest of Kourou in French Guiana (Fig. 1). French Guiana is submitted to a subequatorial climate. The average air temperature fluctuates between 26 and $30^{\circ} \mathrm{C}$, the rainfall ranges from 2500 to $3000 \mathrm{~mm}$ year $^{-1}$. Tides are semi-diurnal with mean high water springs of $1.8 \mathrm{~m}$ (SHOM, 2001). Observations in the field reveal that pioneer to mature mangrove forests are flooded at each tide, whereas the senescent mangrove is only flooded at spring tides, owing to a higher topography. During sampling, the senescent mangrove was covered by a $10-\mathrm{cm}$ layer of freshwater. This mangrove forest, not subjected to an anthropogenic exploitation, is dominated by A. germinans; however, epiphytes, creepers and pteridophytes develop in the senescent forest. Some Rhizophora spp. were also observed in the senescent forest. In the early stages of mangrove evolution, the sediment is covered by different types of algal mats: diatoms, diatoms and cyanophyceae, micro-green algae (De Wit, oral communication). The frequency of biofilms decreases with forest age. Three stages of sedimentation have affected this coastline since 1951. A first stage of accretion, ending in 1966, permitted the development of $1100 \mathrm{~km}^{2}$ of mangrove forest, and was followed by a stage of erosion that lasted until 1991 (Charron, Lointier, Prost, \& Rudant, 1991). Since 1991, a new accretion phase allowed the forest to develop again, sometimes among standing dead trees.

\subsection{Sampling}

Sediment sampling was performed in March 2000 during the 'short summer' at selected sites on the extensive mudflat, NE of the Sinnamary river (Fig. 1). The sediment was completely waterlogged. Thirteen 2-m-deep cores were collected at low tide at sites characterized by their different stages of evolution with an Eijkelkamp gouge anger. The stages of mangrove evolution occur in a clear zonation pattern, which can be recognized in the field. The cores studied in this article were taken during the different stages of mangrove evolution and from the littoral domain: $\mathrm{C} 11$ as pioneer forest, $\mathrm{C} 8$ as young forest, $\mathrm{C} 1$ as young mature forest, $\mathrm{C} 12$ as senescent forest, C2 as 'recolonized' cemetery forest and C6 as shoreface sediment reference ( Table 1). 


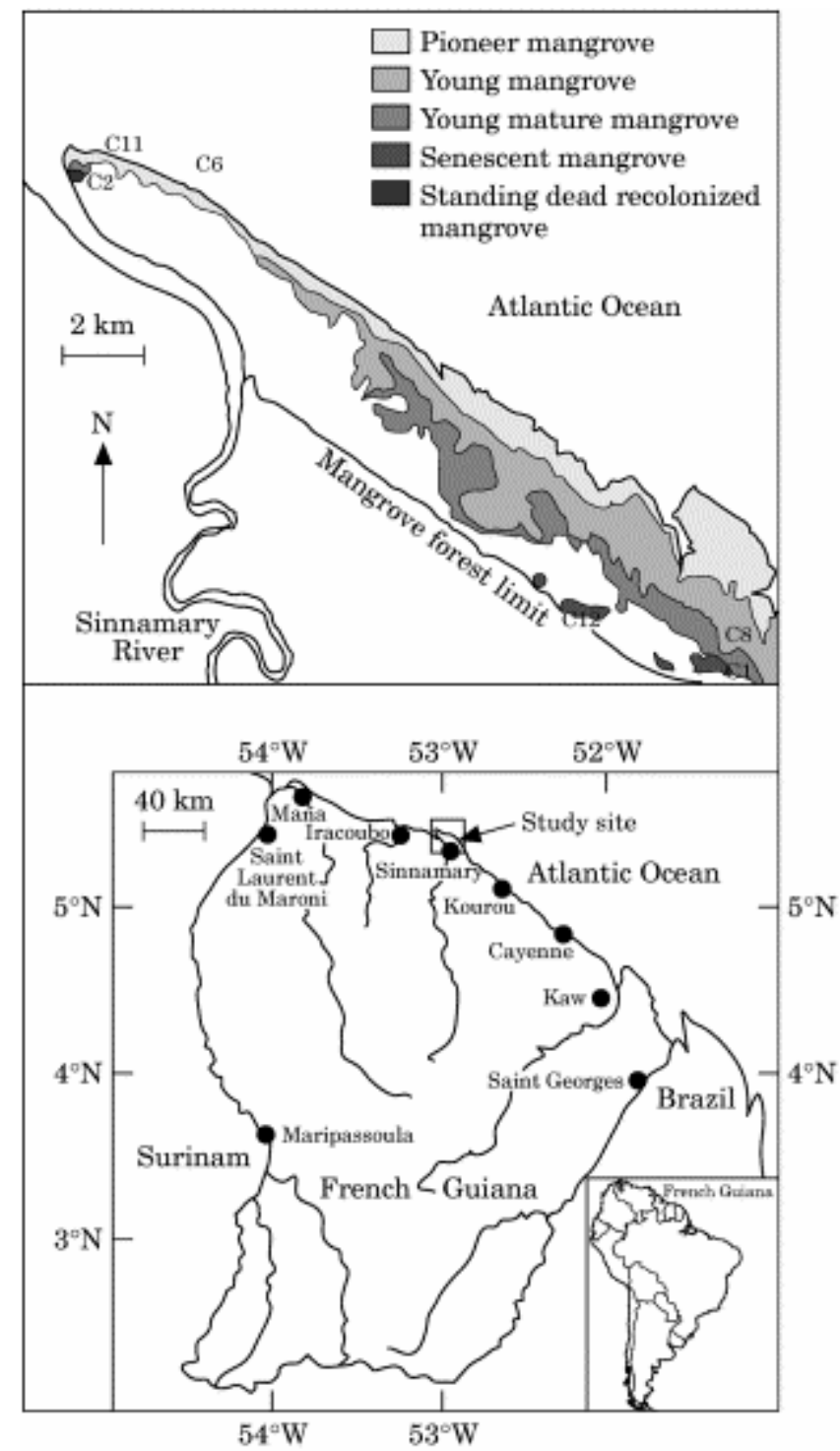

Fig. 1. Map of the study area showing the location of cores (adapted from Fromard et al., 1998).

Table 1. Characteristics of the forest at the six stations

\begin{tabular}{llll}
\hline Station & Location (UTM 22N) & Description & Stage of evolution \\
\hline C1 & $295506 \mathrm{E}-591402 \mathrm{~N}$ & Avicennia germinans $20 \mathrm{~m}$ high & Young mature forest \\
C2 & $278931 \mathrm{E}-602023 \mathrm{~N}$ & Avicennia germinans $4 \mathrm{~m}$ high & 'recolonized' cemetery forest \\
C6 & $280526 \mathrm{E}-602914 \mathrm{~N}$ & Shoreface sediment & Young forest \\
C8 & $295692 \mathrm{E}-591402 \mathrm{~N}$ & Avicennia germinans $10 \mathrm{~m}$ high & Pioneer forest \\
C11 & $279961 \mathrm{E}-602181 \mathrm{~N}$ & Avicennia germinans $1 \mathrm{~m}$ high & Senescent forest \\
C12 & $290854 \mathrm{E}-584706 \mathrm{~N}$ & Avicennia germinans epiphytes, creepers and pteridophytes $30 \mathrm{~m}$ high \\
\hline
\end{tabular}

After collection, the cores were wrapped in plastic film and aluminium foil in order to limit gas exchanges. Samples were taken at: $0-2,2-4,4-6,6-8,8-10,15,20,30,40,50,60,80$, 100,140 and $180 \mathrm{~cm}$ depth and were kept under refrigeration. Sampling and measurements of physico-chemical parameters $(\mathrm{Eh}, \mathrm{pH})$ were performed on the day of coring in an airconditioned laboratory, at the same depths. 


\subsection{Physico-chemical parameters}

$\mathrm{pHs}$ were measured using a glass electrode and a Knick Portamess $\mathrm{pH}$ meter. The $\mathrm{pH}$ electrode was calibrated using 4.02 and 7.00 standards. Redox potential (Eh) was measured, using an $\mathrm{Ag} / \mathrm{AgCl}$ electrode, by inserting the probes directly into a section of core. The $\mathrm{mV}$ meter electrode was checked using demineralized water. The electrodes were equilibrated several minutes before reading values, and they were thoroughly washed and subsequently rubbed with fine emery paper after each measurement in order to prevent the poisoning of electrodes by sulphide ions (Garrels \& Christ, 1965). Results were converted into Eh values, adding $202 \mathrm{mV}$ to the original reading values (AgCl reference electrode, $25^{\circ} \mathrm{C}$ ).

\subsection{Geochemistry}

Total carbon, nitrogen and sulphur contents were determined by combustion at $1100{ }^{\circ} \mathrm{C}$ with a CNS-2000 LECO apparatus. C:N ratio values were obtained by directly calculating the atomic ratio of carbon vs. nitrogen concentration, measured with the LECO analyzer.

The bulk composition of the sedimentary organic matter was determined by Rock-Eval pyrolysis (Rock-Eval Turbo 6) on powdered rock samples (Espitalié et al., 1985 and Lafargue et al., 1998). In the R-E 6, samples are first pyrolysed under inert helium atmosphere, and the residual carbon is subsequently burnt in an oxidation oven. The TOC is determined as the sum of residual and pyrolysed organic carbon contents. Two important parameters are derived from pyrolysis results. The hydrogen index (HI) corresponds to the quantity of pyrolysed hydrocarbon relative to the TOC content. It is the ratio of S2 and TOC, where S2 is the peak of the hydrocarbon released during pyrolysis. It is expressed in $\mathrm{mg} \mathrm{HC}^{-1} \mathrm{TOC}$. The OI represents the amount of oxygen in $\mathrm{mg} \mathrm{CO}_{2} \mathrm{~g}^{-1}$ TOC. This is the ratio of $\mathrm{S} 3$ and TOC, where $\mathrm{S} 3$ is the peak of $\mathrm{CO}_{2}$ liberated during pyrolysis. Most samples were analysed twice. These parameters can give indications on both the amount and source of the sedimentary organic content (Meyers \& Lallier-Vergès, 1999), and the evolution of the humification process ( Disnar, Guillet, Keravis, Massif, \& Di-Giovanni, 2000).

\subsection{Microscopy}

The microscopic examinations of organic matter were carried out using a LEITZ DMRX microscope photometer system, which allows transmitted white light observation, reflected light and incident UV excitation, using oil immersion objectives. Quantitative analyses were performed by surface unit counting on palynofacies preparations with a minimum of 30 ranges and 200 surface units, with an estimated error of $10 \%$ (Noël et al., 2001). These preparations were mounted as smear slides following acid leaching of mineral matter ( Combaz, 1980), and were examined in transmitted light under magnification of $\times 20$ or $\times 50$.

\section{Results}

\subsection{Physico-chemical parameters}

pH measurements, performed on sediments from pioneer to mature forest (Fig. 2), indicated slightly acidic conditions, with mean $\mathrm{pH}$ values close to 6.6. No significant $\mathrm{pH}$ differences were found between sediments from different depths or from forest of different ages. In 
contrast, the pHs of the sediment of senescent forests (C12) were more acidic in surface, values ranging from 5.2 to 6.2 in the uppermost $30 \mathrm{~cm}$ depth.

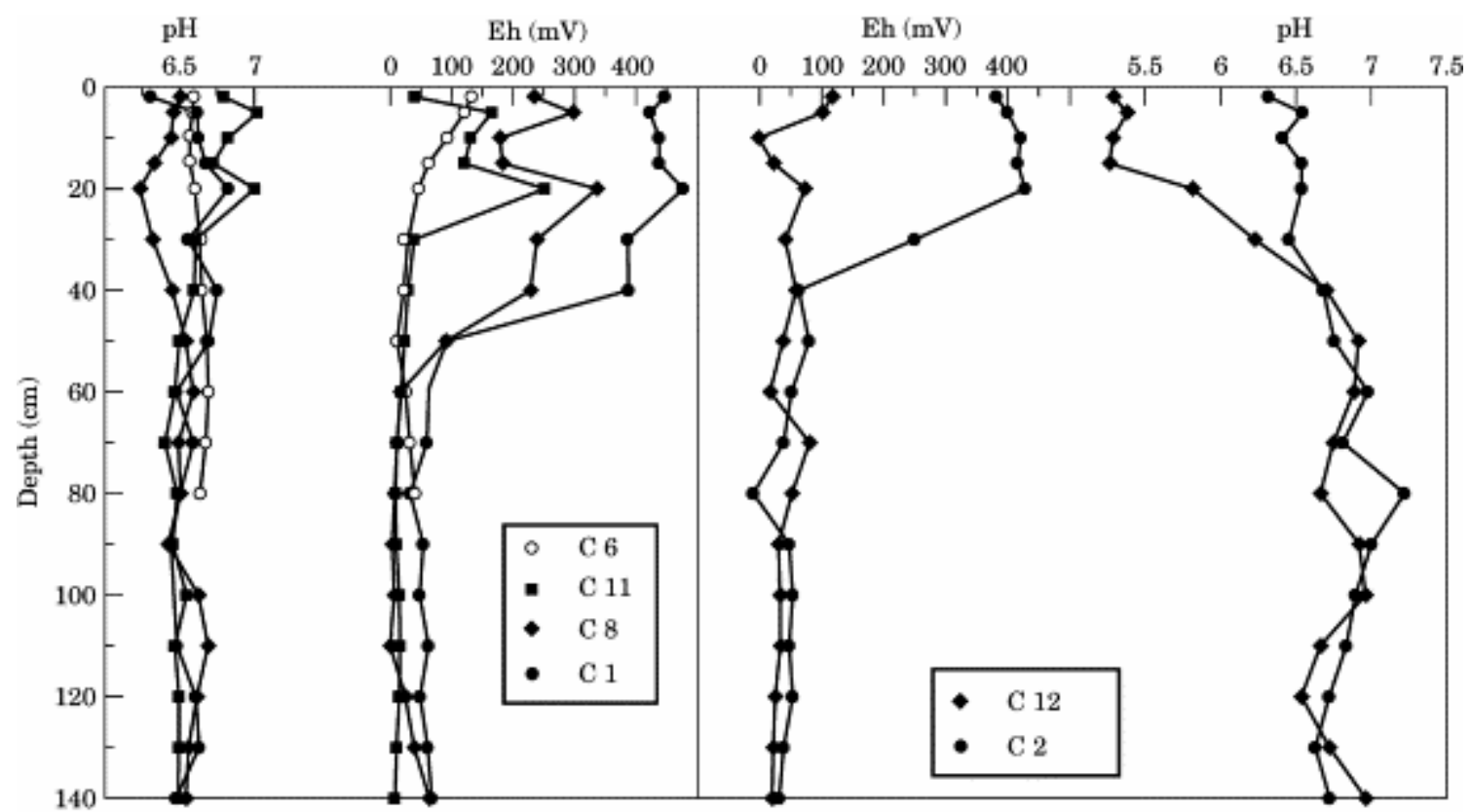

Fig. 2. $\mathrm{pH}$ and Eh trends in sediment profiles of each stage of mangrove evolution.

Eh values (Fig. 2) vary with increasing depth and forest age. Other than in senescent forest, Eh values were very high in the uppermost $30 \mathrm{~cm}$ of cores from the pioneer mangrove and in the uppermost $50 \mathrm{~cm}$ of the cores from the mature mangrove. These maximum values range from $200 \mathrm{mV}$ for the youngest to $480 \mathrm{mV}$ for the mature forest; therefore, Eh values increase with forest evolution. Below these depths, Eh values decrease dramatically and stabilize around $50 \mathrm{mV}$. In the senescent mangrove, Eh values range from 0 to $100 \mathrm{mV}$ along the depth profile.

\subsection{Geochemistry}

The TOC given by the Rock-Eval pyrolyser and the total carbon (TC\%) given by the LECO apparatus are very well correlated, owing to the lack of carbonates. Organic carbon contents presented herein are those obtained from Rock-Eval pyrolysis, whereas C:N ratios are those calculated from the LECO data. Fig. 3, Fig. 4 and Fig. 5represent the depth profiles of geochemical parameters relative to the different stages of mangrove evolution. Geochemical parameters (TOC, C, N, S, IH, IO and C:N ratio) varied significantly among the sites and also with increasing depth. 


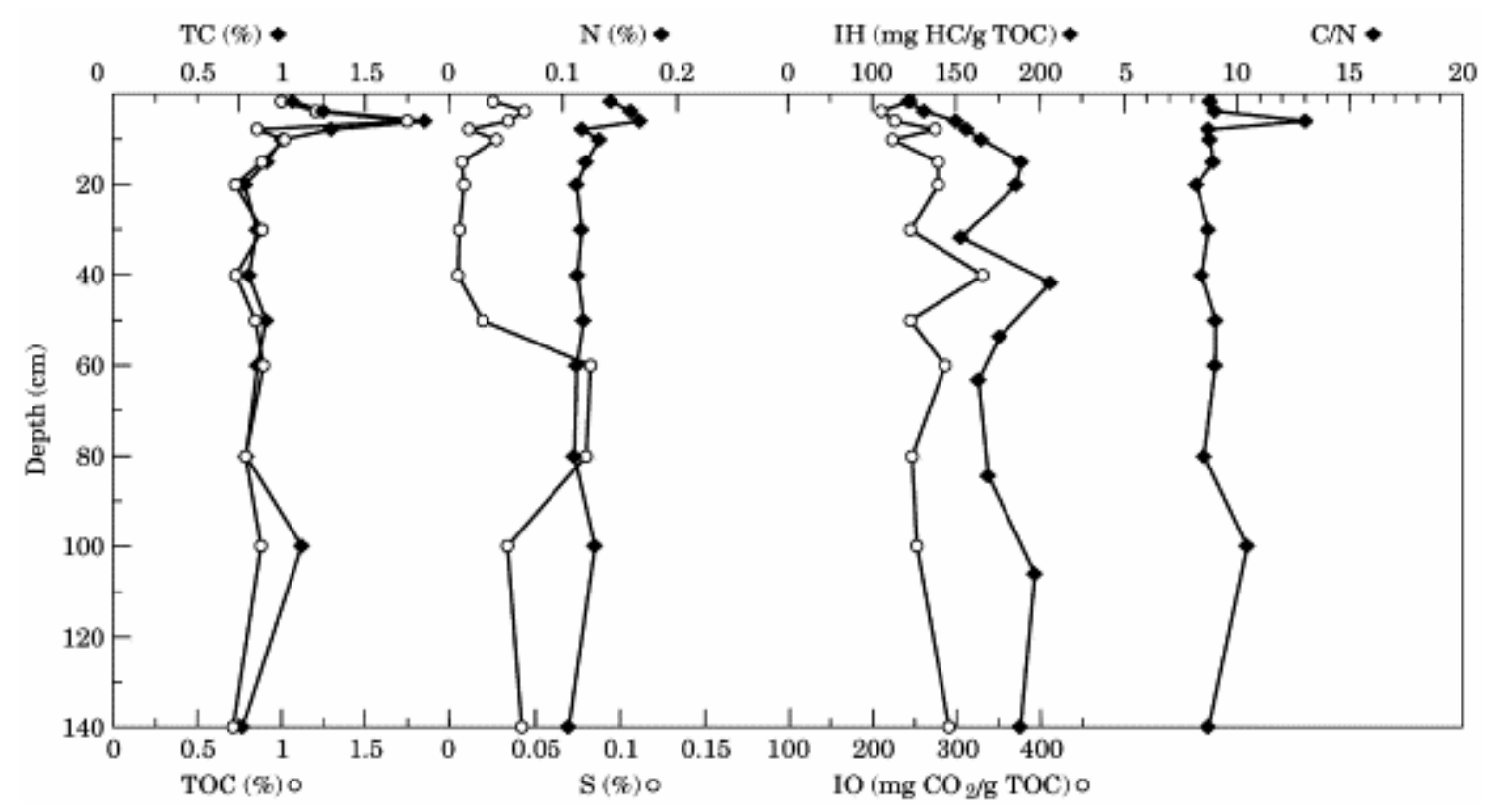

Fig. 3. Vertical profile of organic geochemical data - young mangrove forest sediments (C8).

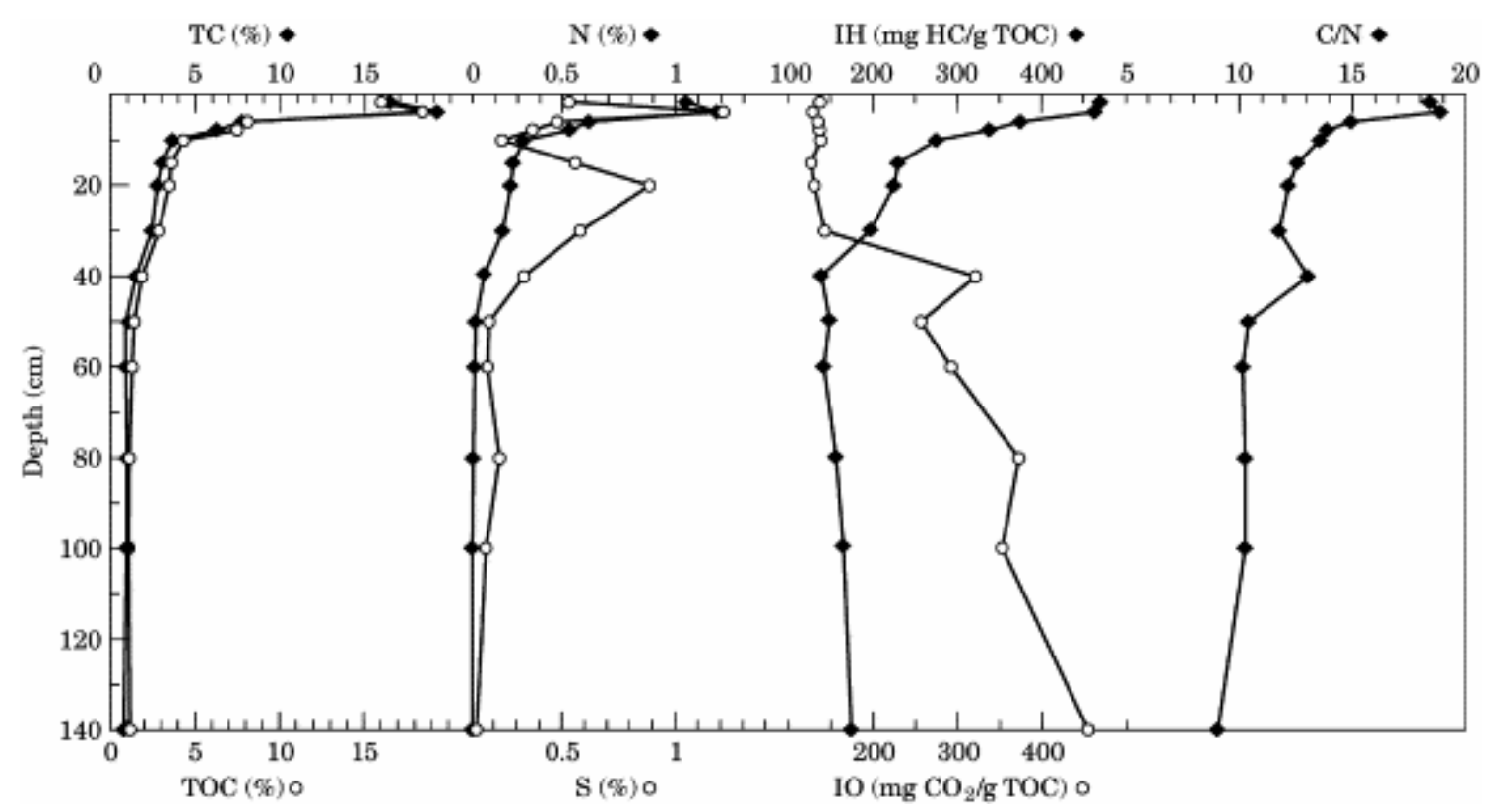

Fig. 4. Vertical profile of organic geochemical data—senescent mangrove forest sediments (C12). 


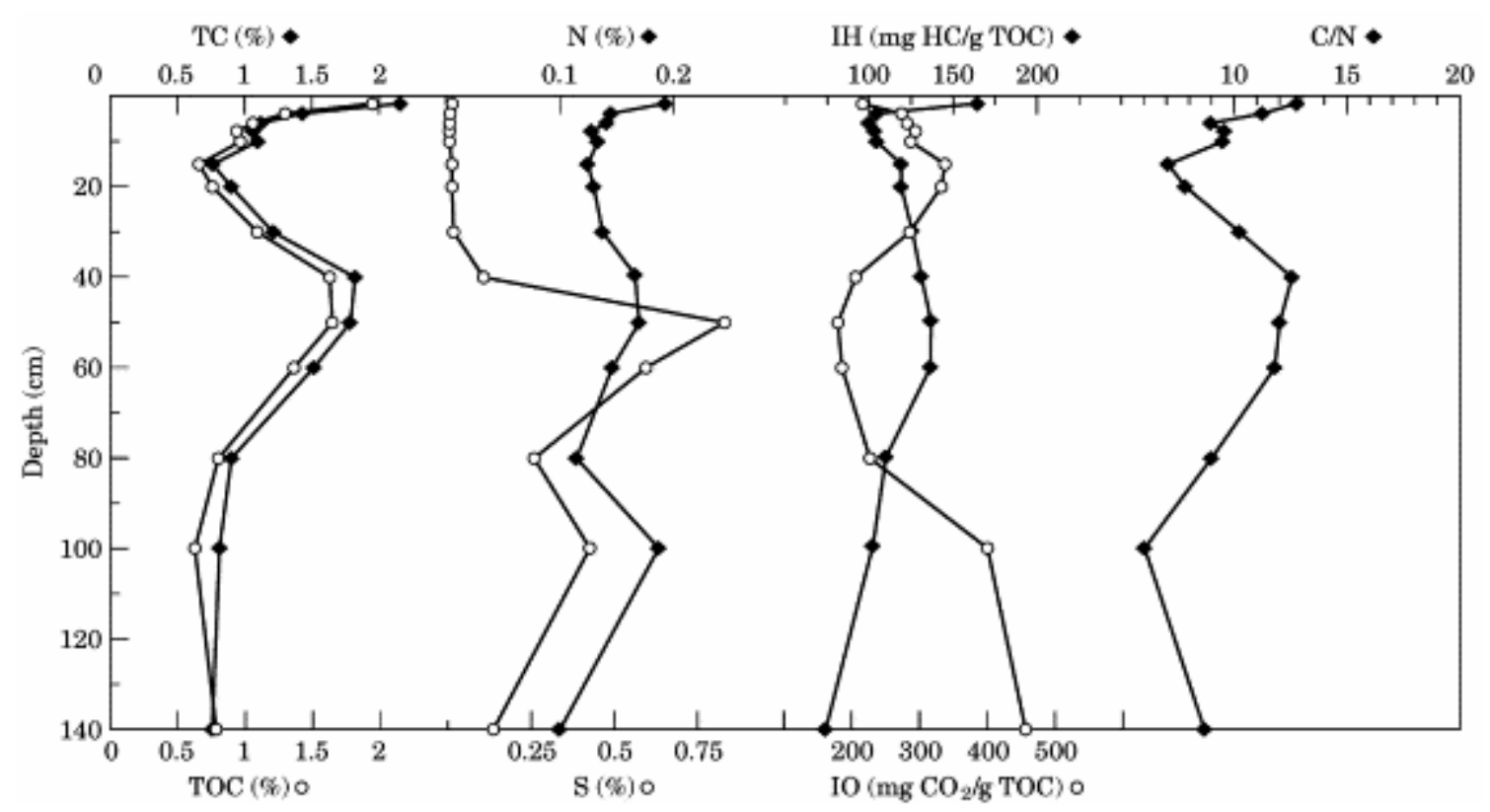

Fig. 5. Vertical profile of organic geochemic data — dead recolonized mangrove forest sediments (C2).

TOC values vary between 0.7 and $19 \%$. The shoreface sediment (C6) presents stable low values, TOC close to $0.7 \%$, whereas the organic content of the mangrove sediment increases with forest evolution. In the pioneer forest, young forest (Fig. 3) and young mature forest, TOCs fluctuate from 1 to $2 \%$ in the uppermost $10 \mathrm{~cm}$ depth. Below this depth, TOCs are close to $0.7 \%$. TOC values of the dead recolonized mangrove sediment (Fig. 5) are close to those of the young forest; however, there is a positive gradient with a maximum of $2 \%$ at $40 \mathrm{~cm}$ depth. In the senescent mangrove (Fig. 4), TOC ranges from $18 \%$ in surface sediments to $0.7 \%$ at 2 m depth.

Total $\mathrm{N}$ content of shoreface sediment is stable at around $0.1 \%$. Variations of total $\mathrm{N}$ follow those of TOC; total $\mathrm{N}$ values range from 0.1 to $0.2 \%$ for the youngest mangrove and rise to $1.3 \%$ for the senescent mangrove (Fig. 4).

Total sulphur content generally exhibits an increase with depth in the upper part of the core followed by a strong decrease downward. The values range from $0 \%$ to a maximum of $1.2 \%$ in surface sediment of the $\mathrm{C} 12$ core (Fig. 4). Total S is not correlated with other parameters. The HI values are not significantly different in the early stages of mangrove evolution. They range from 100 to $200 \mathrm{mg} \mathrm{HC} \mathrm{g}^{-1} \mathrm{TOC}$. However, the $\mathrm{HI}$ values of the sediment from the senescent mangrove (Fig. 4) decreased dramatically from surface, with $470 \mathrm{mg} \mathrm{HC} \mathrm{g}^{-1} \mathrm{TOC}$, down to $40 \mathrm{~cm}$ depth, with $120 \mathrm{mg} \mathrm{HC} \mathrm{g}^{-1} \mathrm{TOC}$. The HI profile of the recolonized mangrove forest (C2) displays the same distribution pattern as that of the TOC profile (Fig. 5).

The OI varies between 200 and $400 \mathrm{mg} \mathrm{CO}_{2} \mathrm{~g}^{-1} \mathrm{TOC}$ for $\mathrm{C} 6, \mathrm{C} 11, \mathrm{C} 8$ and $\mathrm{C} 1$. The IO values of $\mathrm{C} 12$ are very low ( $140 \mathrm{mg} \mathrm{CO}_{2} \mathrm{~g}^{-1}$ TOC) in the upper part, then begin to rise from $40 \mathrm{~cm}$, reaching $450 \mathrm{mg} \mathrm{CO}_{2} \mathrm{~g}^{-1} \mathrm{TOC}$ at $140 \mathrm{~cm}$ depth(Fig. 5). The OI profile of the recolonized mangrove forest (C2) displays a distribution pattern, which is the reverse of TOC and HI distributions ( Fig. 5).

The C:N ratios of bulk sediment are quite low, ranging from 7 to 19 . They characterize organic matter derived from algae or phytoplankton, whereas vascular land plants generally 
have a C:N ratio of 20 or more (Meyers, 1994). These differences are due to the original carbon richness of the lignin and cellulose constituting the higher plants and the original nitrogen richness of the proteins constituting algal matter. The $\mathrm{C}: \mathrm{N}$ ratios of roots have also been analyzed herein. The values, ranging from 30 to 82 , are significantly higher than the bulk sediment. This difference between bulk sediment and roots of A. germinans is similar to that observed between bulk sediment and roots of Ceriops or Rhizophora (Middelburg, Nieuwenhuize, Slim, \& Ohowa, 1996). For all the cores, C:N ratios display the same distribution pattern as that of the TOCs ( Fig. 3, Fig. 4 and Fig. 5). The C:N values are significantly greater (reaching 18 in the uppermost part) in the senescent mangrove (C12) than in other forests. The results for the recolonized forest ( $\mathrm{C} 2$ core) are slightly different from those of other cores because numerous parameters (TOC, C:N, Total S and pyrite framboid content) exhibit positive gradients between 15 and $80 \mathrm{~cm}$ depth, whereas all other cores show rather low and stable parameters.

\section{Optical results}

\subsection{Petrographic composition}

Organic components include recognizable vegetal debris, i.e. partially to completely degraded land-derived tissues and algae. Diatom tests have been observed in total sediment smear slides in the upper part of cores.

Plant tissues show different states of preservation:

Well-preserved translucent ligno-cellulosic debris (TLC), still exhibiting perfectly preserved cell-wall structures showing only a minor alteration and no morphological changes. The cell cytoplasm is lacking, but cellulose is still present in the cell walls, which are thick. No tannin granules are observed. These tissues are only present in surface samples.

Ligno-cellulosic tissues may exhibit several types of peatification and oxidation:

Degraded ligno-cellulosic debris (DLC): cell-walls are thick and dislocated, cell-lumens contain brown material. This material could be the result of the decay of secondary cell walls (Stout \& Spackman, 1987), which are chemically degraded.

Gelified particles (GP): the morphology of these orange-brown gel-like particles depends on the shape of original cells (Lallier-Vergès et al., 1998). They usually occur in the form of rounded polygonal debris and are probably produced by the degradation of cellulose as proposed by Stout and Spackman, 1987 and Cohen et al., 1987. They are scarce.

Reddish amorphous organic matter (RAOM): these correspond to the complete degradation of ligno-cellulosic tissues, which may occur during the alteration of vegetal debris under water (Bourdon et al., 2000). The total degradation of woody tissues seems to be due to the hydrolysis of cellulose, which induces a further oxidation of lignin and a deterioration in the structural integrity of wall ( Stout \& Spackman, 1987).

Oxidized opaceous ligno-cellulosic debris (OLC): these are dark, structureless debris of small size, which can be elongated or rounded. They represent a very refractory OM derived from the land biomass after prolongated oxidation phases. 
Spores and pollen: these are very scarce.

All the proportions of autochthonous higher plant debris, i.e. other than OLC, were added in order to be compared with algae proportions.

The algaa- and phytoplankton-derived organic matter are present in all the cores as recognizable remnants or as greyish amorphous organic matter (GAOM); the latter are structureless flakes whose colour varies between grey, brown and black, depending on their thickness. They have various shapes and their outlines are diffuse.

Pyrite framboids, either dispersed or included in the cell-lumens of vegetal debris, indicate the presence of both sulphur and reducing conditions.

\subsection{Petrographic evolution}

Fig. 6, Fig. 7 and Fig. 8present the depth profiles of different stages of mangrove evolution. The petrographic organic composition, i.e. the proportions between the various components, is significantly different in each core. The evolution of these components as a function of mangrove evolution is correlated with geochemical data. Firstly, the shoreface sediment is characterized by a dominant algal-derived GAOM; the land-derived debris, present in low proportions, are essentially highly degraded higher plant debris, and correspond to reworked refractory material. Then, the proportion of well-preserved autochthonous ligno-cellulosic debris rises with forest age: they may represent more than $20 \%$ of the components in the upper part of these cores. Their maximum is situated at $10 \mathrm{~cm}$ depth; under this depth, their proportion falls dramatically. The evolution of the degraded ligno-cellulosic debris follows that of the well-preserved ones; however, their proportion may be larger and they occur at greater depths. For example, they represent more than $30 \%$ up to a depth of $30 \mathrm{~cm}$ in $\mathrm{C} 12$ core (senescent mangrove). The percentage of pyrite framboids sometimes correlates with those of degraded debris. The greater percentage of pyrite is $15 \%$ at $20 \mathrm{~cm}$ depth of the $\mathrm{C} 12$ core, where degraded tissues (DLC) and total S contents are at their maximum. For the other cores, the percentage of pyrite ranges from 0 to $5 \%$ except for the dead recolonized mangrove, where it reaches $11 \%$. In this case, the proportion begins to increase at $30 \mathrm{~cm}$ depth, where the organic content is greater. The percentage of oxidized ligno-cellulosic debris rises with depth; it ranges from 8 to $15 \%$ for young mature forest. This increase only reflects a dilution at the surface by autochthonous debris. Concerning the senescent forest (Fig. 7), the proportion of the oxidized debris is much greater $(40 \%$ at $140 \mathrm{~cm}$ depth). The percentage of RAOM ranges from 5 to $20 \%$, the senescent forest being richer in RAOM (approximately 20\%) than the other forests (approximately 10\%). There is no significant change with depth for this component. The greyish GAOM is the main component for all cores and represents from 20 to $70 \%$ of the total organic content. The minimum of this algae-derived organic matter $(20 \%)$ occurs in the senescent forest. In contrast, the maximum values are observed in the pioneer mangrove. The GAOM proportion decreases with the age of the mangrove forest. 


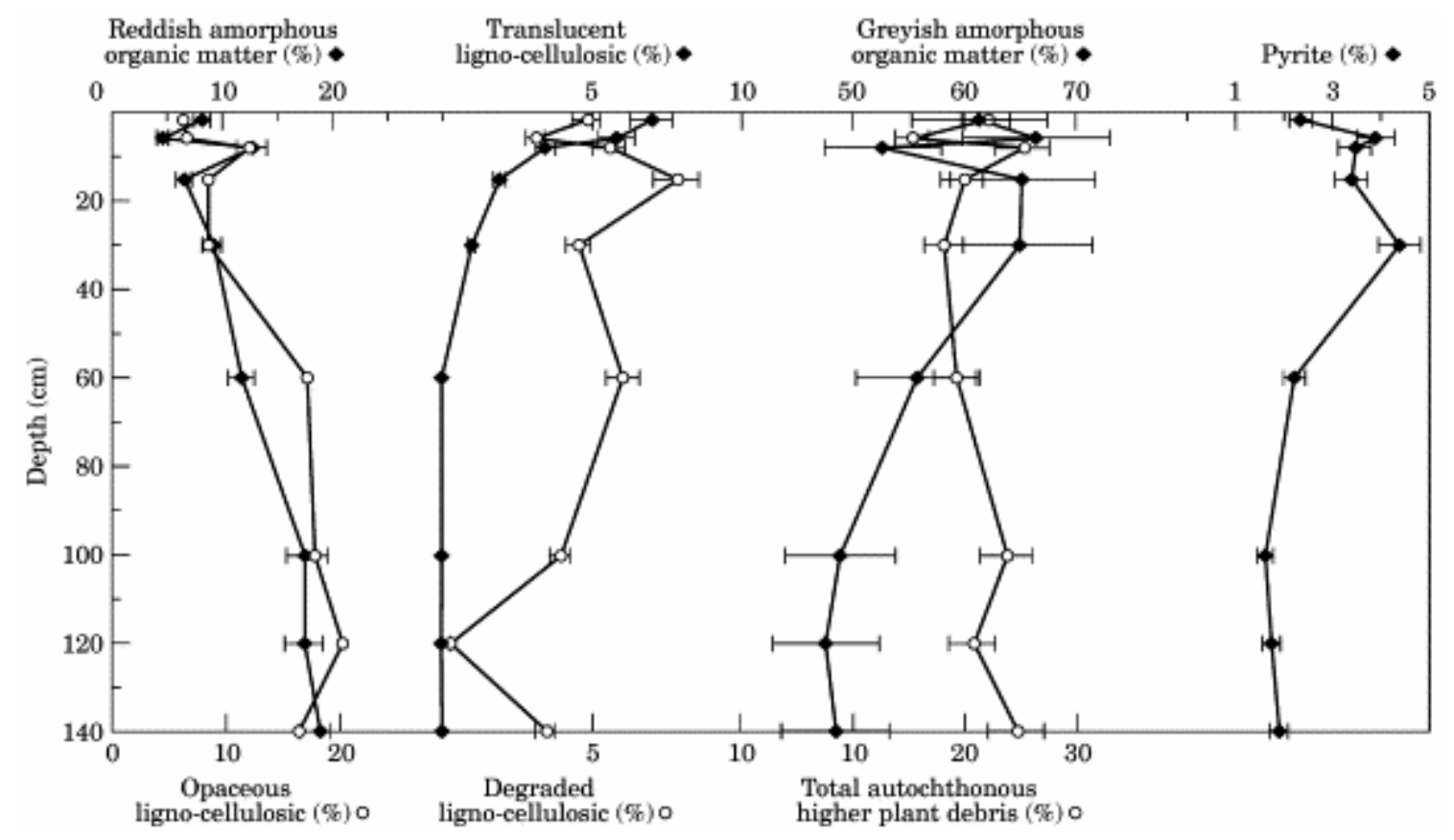

Fig. 6. Vertical profile of petrographic constituents—young mangrove forest sediments (C8). Bars depict $\pm 10 \%$.

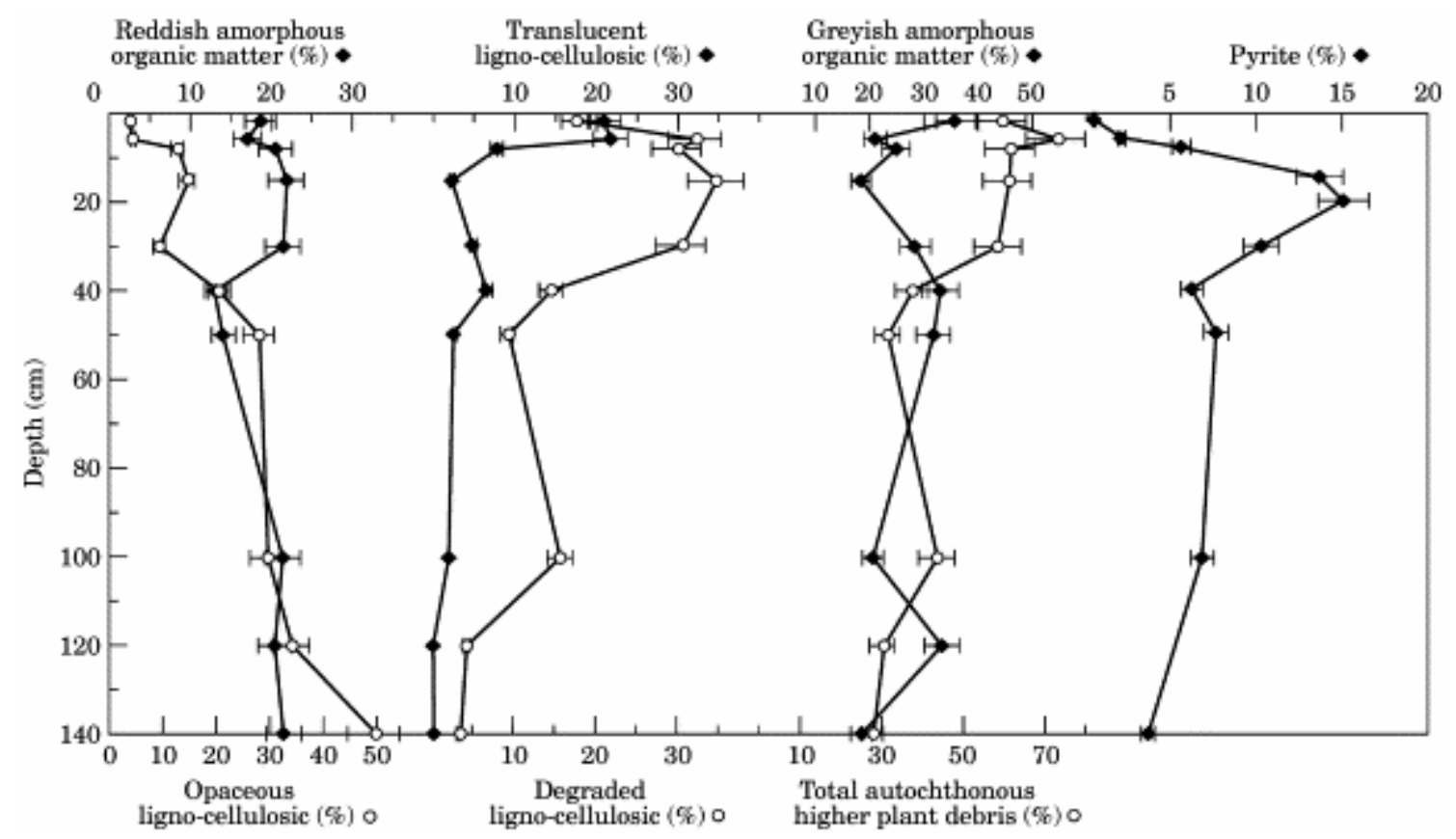

Fig. 7. Vertical profile of petrographic constituents—senescent mangrove forest sediments (C12). Bars depict $\pm 10 \%$. 


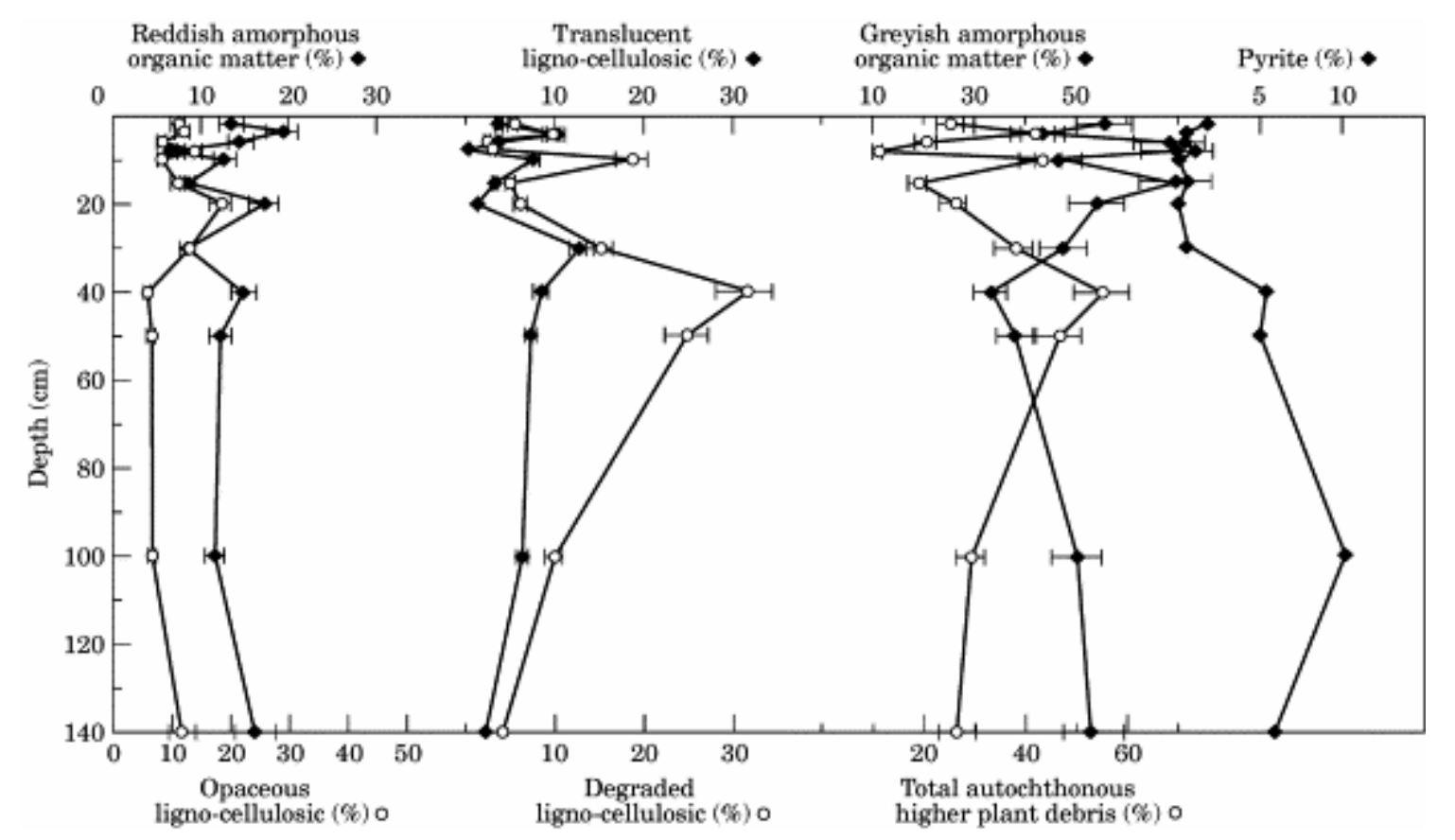

Fig. 8. Vertical profile of petrographic constituents — dead recolonized mangrove forest sediments (C2). Bars depict $\pm 10 \%$.

\section{Discussion}

\subsection{Redox conditions}

Geochemical characteristics of mangrove sediment depend on various parameters, such as organic matter content, water table fluctuation, bioturbation (Clark,McConchie, Lewis, \& Saenger, 1998), vegetation species ( Nickerson and Thibodeau, 1985 and Kryger and Lee, 1996) and ground-water movement (Baltzer, 1982 and Baltzer et al., 1995). The pH values are similar to those of African Avicennia forest, ranging from 6.2 to 8 (Middelburg et al., 1996), and of Australian Avicennia forest, ranging from 5.5 to 8 (Clark et al., 1998).

Many mangroves are characterized by negative redox potentials close to sediment surface, down to $-400 \mathrm{mV}$ for Eo in Guadeloupe (Lallier-Vergès et al., 1998) and down to $-300 \mathrm{mV}$ in New Caledonia (Baltzer, 1982) because of frequent tidal submersion by sea water of a finegrained sediment and enhanced organic degradation. However, our results suggest suboxic conditions ( Reeburgh, 1983) with an increase of Eh values from the pioneer to the mature mangrove forest for quite a similar organic content (1\% TOC in pioneer mangrove to $2.4 \%$ TOC in young mature mangrove). These high values may be explained by different factors, biological or physical. First, the sediment may be oxygenated by vegetation. Avicennia trees are known for their extensive radial cable roots with pneumatophores, which constitute a pathway for the exchange of oxygen between atmosphere and sediment (Scholander, Van dam, \& Sholander, 1955). Earlier studies ( Thibodeau \& Nickerson, 1986) highlighted that Avicennia roots create oxidized rhizosphere larger than in other species. In Jamaica, the output of $\mathrm{O}_{2}$ from the roots was estimated between 28 and $179 \mathrm{mmol} \mathrm{O}_{2} \mathrm{~m}^{-2}$ day $^{-1}$ (Nedwell et al., 1994). Moreover, intense bioturbation by mud crabs may also allow oxygenation through gas exchanges between atmosphere and sediment ( Baltzer, 1982). Indeed, the orifices of numerous burrows are visible on the sediment surface. Secondly, such conditions 
may be obtained with a decrease of the water table during dry season; however, at the time of sampling, the sediment was still completely waterlogged. Moreover, the older the forest, the deeper in the sediment the oxidizing values, probably due to the growth of the root system. Finally, another reason may be the lack of reactive organic matter. Recent experiments obtained with micro-electrode system have revealed that the conditions may be totally anoxic within the surficial millimetres of algal mats, whereas just below the algal biofilms, the conditions were fully oxic (De Wit et al., 1989 and De Wit, 2000). These results suggest that under the uppermost reactive organic layer, there is not enough metabolizable OM available in the sediment for consuming oxygen. Indeed, our results show that the sedimentary OM is globally very resistant and refractory to degradation. Our results partially corroborate the redox model described by Clark et al. (1998), with four oxidation and reduction zones in an Avicennia-dominated forest on the basis of similar Eh measurements. In the Sinnamary mangrove, the upper reduction zone either did not exist at the time of our measurements, or only existed within the algal mats (not measured). However, a decrease in Eh is observed at the corresponding depth (between 10 and $15 \mathrm{~cm}$ ) for cores 11 and 8, i.e. in the youngest forest. The upper oxidation zone and the lower oxidation zone (zone of maximum root activity), defined by Clark et al., merge probably due to the root activity and crab bioturbation. The lower Eh values are observed in the uppermost level of the senescent mangrove as a result of the enhanced decay process of abundant organic matter from the forest.

\subsection{Nature of the sedimentary organic matter}

The nature of deposited organic matter plays a dominant role in the final determination of the sediment composition (Patience, Lallier-Vergès, Albéric, Tribovillard, \& Desprairies, 1996). Algal-derived organic matter is much reactive to decomposition than higher-plant-derived organic matter. In this study, TOC values are much lower than in the stable mangrove swamp of Guadeloupe ( Lallier-Vergès et al., 1998), but are close to those found in Malaysia (Alongi et al., 1998) and in Australia ( Clark et al., 1998); however, different origins were determined. Actually, the sedimentary organic matter of this Avicennia mangrove forest is a blend of allochthonous and autochthonous constituents. Firstly, the allochthonous OM is represented by the minute debris of reworked oxidized ligno-cellulosic debris as observed in the optical study. Their fairly constant proportion, in the shoreface sediment and in the early stages of forest evolution, is a clear indication that these components are transported by the Amazon river discharge. Secondly, various kinds of autochthonous organic matter were identified on the basis of $\mathrm{C}: \mathrm{N}$ ratios and optical observations, for which two origins were determined. On one hand, algal-derived OM is characterized by low $\mathrm{C}: \mathrm{N}$ ratio and is represented in optical study by the greyish amorphous OM. On the other hand, higher-plant-derived OM is characterized by higher $\mathrm{C}: \mathrm{N}$ ratio and appears in optical study as various types of lignocellulosic debris. For the first stage of mangrove forest evolution, $\mathrm{C}: \mathrm{N}$ ratios are low, and the petrographic study reveals a predominance of algal OM controlling the TOC increase in surface sediment. Nevertheless, HIs are low, a clear indication that algal OM is quickly degraded. The sedimentary record of the development of higher plant only occurs from the young mature forest. Three hypotheses may explain this trend: (i) a low plant biomass of the younger stages, the above ground biomass is around $35 \mathrm{tha}^{-1}$ (Fromard et al., 1998); (ii) the consumption of the leaves by fauna; and (iii) the tidal flushing, as observed on field. The litter of this lower forest is effectively removed with every tide. Tidal flushing may represent the major form of particulate carbon export in Australian mangroves ( Boto and Bunt, 1981 and Boto and Wellington, 1988). Nevertheless, the first stages of forest evolution are recorded in sediments owing to the development of the lateral root system, which induces an increase in 
TOC and $\mathrm{C}: \mathrm{N}$ ratio between 5 and $10 \mathrm{~cm}$ depth. This trend is also underlined by an increase in ligno-cellulosic debris. Organic matter derived from roots is known to represent a large part of the sedimentary organic matter in mangrove forest (Perrussel, Lallier-Vergès, Baltzer, Disnar, \& Rivière, 1999). Chen and Twilley (1999) suggest that the rates of root production are critical processes in controlling the accumulation of organic matter. The accumulation of organic carbon is much higher in the senescent mangrove forest, which is rarely flooded by tide. The relatively high $\mathrm{C}: \mathrm{N}$ values are close to those found in south-eastern Brazil for the same species ( Lacerda et al., 1995). This organic carbon is derived from the higher plants. In contrast with other evolution stages, this organic matter is also characterized in surface sediment by very high HI values, which means that this matter derived from higher plants is still very preserved. For increasing ages, the depth exhibiting autochthonous higher-plantderived $\mathrm{OM}$ is deeper. This trend gives another tool to follow the development of the mangrove forest.

\subsection{Early diagenetic conditions}

These results, which display a lateral-age evolution, show differences in sediment biogeochemistry among the mangrove forests. On one hand, the first stages of forest evolution, from pioneer to young mature mangrove, which are both frequently flooded, exhibit a low increase in TOC and an increase in Eh values with the forest age. On the other hand, the senescent mangrove, rarely submerged owing to a difference of micro-topography, exhibit relatively high TOC, lower Eh and $\mathrm{pH}$ values. These data also indicate major differences in the evolution of the sedimentary organic matter. The decrease in TOC content and $\mathrm{C}: \mathrm{N}$ ratio indicate a rapid decomposition of the organic matter derived from roots in the young mangrove and from litter in the mature mangrove. The efficient degradation is underlined by a dramatic decomposition of ligno-cellulosic debris. No clear relationship has been observed between HI, OI and the organic composition during these early stages of mangrove evolution, this is due to the low enrichment of the sediment in organic matter. The very low content in both sedimentary total sulphur and observed pyrite, and the Eh profile suggest that suboxic processes dominate the early diagenesis in the young Avicennia mangrove forest and that local anaerobic conditions may occur in micro-environments. These decay processes may be explained by the activity of Avicennia roots. Such processes of decomposition have been observed in various mangroves (Nedwell et al., 1994; Alongi et al., 1998 and Alongi et al., 1999). The early diagenetic conditions are completely different in the senescent mangrove. These differences may be explained by the higher delivery of organic matter in sediment resulting from the intense development of the vegetation and the fact that litter appears not to be flushed by tides. The latter environmental parameters induce lower Eh values. Sulphate-reducing conditions and bacterial activity are also highlighted by lower $\mathrm{pH}$ values and an increase in total $\mathrm{S}$ content correlated with an increase in pyrite framboids, known to depend on the concentration of easily reducible iron minerals and the availability of metabolizable organic matter by sulphate-reducing bacteria (i.e. Berner, 1970). The nature and the decay processes of organic matter may also be approached by the Rock-Eval results. The HI and OI values are relatively stable in sediment with depth, for the youngest mangrove forests (see $\mathrm{C} 8$ core). However, the senescent mangrove exhibits a very specific profile with a drastic diminution of $\mathrm{HI}$ values in the uppermost $30 \mathrm{~cm}$ (460 to $150 \mathrm{mg} \mathrm{HC} \mathrm{g}^{-1} \mathrm{TOC}$ ), whereas OI values remain stable. This peculiar trend has to be related to the early decay of higher plant debris, which first affects the easily degradable hydrogen bounds. The rise in OI values in the deeper part of the senescent mangrove core is correlated with the rise of oxidized ligno-cellulosic debris content, reflecting the different nature of organic matter in the underlying sediment. 
The positive gradient of the dead recolonized mangrove clearly underlines the previous phase of mangrove forest development, therefore, a previous phase of erosion and accretion. The presence of standing dead trees favours the hypothesis of a phase of sedimentation rather than a phase of erosion: a new supply of sediment may have caused the death of trees by smothering the roots (Ellison, 1998). Various parameters are close to those of the senescent mangrove (low Eh, high pyrite framboid content, high sulphur content) and highlight sulphate-reducing processes. This suggests that the forest may have attained a senescent stage before being buried.

\section{Conclusions}

According to the previous discussion, the organic sedimentary content of the mangrovefringed coast of French Guiana appears to be a blend of an allochthonous refractory part derived from Amazon river detritus and an autochthonous reactive part derived from algal mats and mangrove trees. The combined optical and geochemical approaches provide evidence that the sedimentary organic content and the decay processes are influenced by the growth of the mangrove forest. Each stage of evolution exhibits its own characteristics; however, two main systems are highlighted with differences in the origin of the organic matter and in early diagenetic conditions. The sedimentary organic content of the early stages of mangrove evolution is very low, and mainly derived from algal mats and scarce Avicennia roots. The restricted organic accumulation may also be partly linked to the tidal flushing. However, older the forest greater the organic content. The organic content quickly decreases with depth in the sediment due to the decay processes thought to be suboxic and induced by biological processes - sediment oxygenation by the A. germinans roots and the crab bioturbation - rather than physical processes. In contrast, the organic content of the senescent mangrove forest is mainly derived from higher plants. The accumulation of organic matter is 10 times greater. Moreover, decay processes seem to be anoxic sulphate-reducing ones. The low thickness of the enriched carbon layer reflects the highly dynamic feature of this very specific coastal environment. The organic matter profiles of the recolonized mangrove reveal previous phases of erosion followed by a new accretion.

\section{Acknowledgements}

This work is part of a research program supported by both NSF and CNRS. We would like to thank R. Aller (State University of New York, Stony Brook, USA), M. Allison (Tulane University, New-Orleans, USA), F. Fromard and C. Vega (Université Paul Sabatier, Toulouse, France) for their valuable assistance in field sampling. We would also like to thank M. Hatton and D. Keravis (ISTO, Orleans, France) for their technical assistance. Finally, we thank Patrick Albéric and Jean-Robert Disnar (ISTO, Orléans, France) for fruitful discussions.

\section{References}

Allison, M.A., Lee, M.T., Ogston, A.S. and Aller, R.C., 2000. Origin of Amazon mudbanks along the northeastern coast of South America. Marine Geology 163, pp. 241-256.

Alongi, D.M., Sasakumar, A., Tirendi, F. and Dixon, P., 1998. The influence of stand age on benthic decomposition and recycling of organic matter in managed mangrove forests of Malaysia. Journal of Experimental Marine Biology and Ecology 225, pp. 197-218. 
Alongi, D.M., Tirendi, F. and Clough, B.F., 2000. Below-ground decomposition of organic matter in forests of the mangrove Rhizophora stylosa and Avicennia marina along the arid coast of Western Australia. Aquatic Botany 68, pp. 97-122.

Alongi, D.M., Tirendi, F., Trott, L.A. and Brunskill, G.J., 1999. Mineralisation of organic matter in intertidal sediments of a tropical semi-enclosed delta. Estuarine, Coastal and Shelf Science 48, pp. 451-467.

Baltzer, F., 1982. La transition eau douce-eau salée dans les mangroves: Conséquences sédimentologiques et géochimiques. Bulletin de la Société Géologique de France 144, pp. 2742 .

Baltzer, F., Plaziat, J. C., \& Rudant, J. P. (1995). Long term effect of seasonal changes on geochemical properties of sediments in mangrove swamps under equatorial climate. In French Guiana. Workshop Ecolab, Brazil.

Berner, R.A., 1970. Sedimentary pyrite formation. American Journal of Science 268, pp. 123.

Boto, K.G. and Bunt, J.S., 1981. Tidal export of particulate organic matter from a Northern Australian mangrove system. Estuarine, Coastal and Shelf Science 13, pp. 247-255.

Boto, K.G. and Wellington, J.T., 1988. Seasonal variations in concentration and fluxes of dissolved organic and inorganic materials in a tropical, tidally-dominated, mangrove waterway. Marine Ecology Progress Series 50, pp. 151-160.

Bourdon, S., Laggoun-Défarge, F., Disnar, J.R., Maman, O., Guillet, B., Derenne, S. and Largeau, C., 2000. Organic matter and early diagenetic degradation in a tropical peaty marsh (Tritrivakely, Madagasgar). Implications for environmental reconstruction during the SubAtlantic. Organic Geochemistry 31, pp. 421-443.

Buillit, N., Lallier-Vergès, E., Pradier, B. and Nicolas, G., 2002. Coal petrographic genetic units in deltaic-plain deposits of the Campanian Mesa Verde Group (New Mexico, USA). International Journal of Coal Geology 51, pp. 93-110. SummaryPlus | Full Text + Links | PDF $(757 \mathrm{~K})$

Charron, C., Lointier, M., Prost, M. T., \& Rudant, J. P. (1991). Etude multitemporelle du littoral et des estuaires Guyanais utilisant l'imagerie Spot et Landsat. In Symposium PICG 274/ORSTOM sur l'évolution des littoraux de Guyane et de la Caraibe Méridionale (pp. 151158).

Chen, R. and Twilley, R.R., 1999. A simulation model of organic matter and nutrient accumulation in mangrove wetland soils. Biogeochemistry 44, pp. 93-118.

Clark, M.W., McConchie, D., Lewis, D.W. and Saenger, P., 1998. Redox stratification and heavy metal partitioning in Avicennia-dominated mangrove sediments: a geochemical model. Chemical Geology 149 3-4, pp. 147-171.

Cohen, A.D., Spackman, W. and Raymond, R.J., 1987. Interpreting the characteristic of coal seams from chemical, physical and petrographic studies of peats deposits. In: Scott, A.C., 
Editor, , 1987. Coal and coal bearing strata: recent advancesGeological society special publication Vol. 32.

Combaz, A., 1980. Les kérogènes vus au microscopeKerogen, Technip, Paris 549 pp. .

De Wit, R., 2000. Sulfide-containing environments. In: Lederberg, J., Editor, , 2000. (2nd ed.),Encyclopedia of microbiology Vol. IV, Academic Press, San Diego, pp. 478-494.

De Wit, R., Jonkers, H.M., Van den Ende, F.P. and Van Gemerden, H., 1989. In situ fluctuations of oxygen and sulphide in marine microbial sediment ecosystems. Netherlands Journal of Sea Research 23, pp. 271-281.

Disnar, J. R., Guillet, B., Keravis, D., Massif, R., \& Di-Giovanni, C. (2000). Soil organic matter (SOM) characterization by Rock-Eval pyrolysis: main classical parameters. In Tenth international meeting of the international humic substances society: Vol. 2 (pp. 1211-1214).

Ellison, J.C., 1998. Impacts of sediment burial on mangroves. Marine Pollution Bulletin 37 8-12, pp. 420-426.

Espitalié, J., Deroo, G. and Marquis, F., 1985. La pyrolise Rock-Eval et ses applications. $1^{\circ}$ partie. Revue de l'Institut Français du Pétrole 40, pp. 563-579.

Fromard, F., Puig, H., Mougin, E., Marty, G., Betoulle, J.L. and Cadamuro, L., 1998. Structure, above ground biomass and dynamics of mangrove ecosystems: new data from French Guiana. Oecologia 115, pp. 39-53.

Garrels, R.M. and Christ, C.L., 1965. Solution, minerals and equilibria. , Harper and Row, New York 450. pp. .

Huc, A.Y., 1980. Origin and formation of organic matter in recent sediments and its relation to kerogen. In: Durand, B., Editor, , 1980. Kérogène: Matière organique insoluble des roches sédimentaires, Technip, Paris, pp. 446-474.

Kryger, L. and Lee, K., 1996. Effects of mangrove soil ageing on the accumulation of hydrogen sulphide in roots of Avicennia spp. Biogeochemistry 35, pp. 367-375.

Lacerda, L.D., Ittekkot, V. and Patchineelam, S.R., 1995. Biogeo-chemistry of mangrove soil organic matter: a comparison between Rhizophora and Avicennia soils in south-eastern Brazil. Estuarine, Coastal and Shelf Science 40, pp. 713-720.

Lafargue, E., Marquis, F. and Pillot, D., 1998. Rock-Eval 6 applications in hydrocarbon exploration, production, and soil contamination studies. Revue de l'Institut Français du Pétrole 53 4, pp. 421-437.

Lallier-Vergès, E., Perrussel, B., Disnar, J.R. and Baltzer, F., 1998. Relationships between environmental conditions and the diagenetic evolution of organic matter derived from higher plants in a modern mangrove swamp system (Guadeloupe, French West Indies). Organic Geochemistry 29, pp. 1663-1686. 
Meyers, P.A., 1994. Preservation of elemental and isotopic source identification of sedimentary organic matter. Chemical Geology 114, pp. 289-302.

Meyers, P.A., 1997. Organic and geochemical proxies of paleo-oceanographic, paleolimnologic and paleoclimatic processes. Organic Geochemistry 27, pp. 213-250.

Meyers, P.A. and Lallier-Vergès, E., 1999. Lacustrine sedimentary organic matter records of Late Quaternary paleoclimates. Journal of Paleolimnology 21, pp. 345-372.

Middelburg, J.J., Nieuwenhuize, J., Slim, F.J. and Ohowa, B., 1996. Sediment biogeochemistry in an East African mangrove forest (Gazi Bay, Kenya). Biogeochemistry 34, pp. 133-155.

Nedwell, D.B., Blackburn, T.H. and Wiebe, W.J., 1994. Dynamic nature of the turnover of organic carbon, nitrogen and sulfur in the sediments of a Jamaican mangrove forest. Marine Ecology Progress Series 110, pp. 223-231.

Nickerson, N.H. and Thibodeau, F.R., 1985. Association between pore water sulphide and distribution of mangroves. Biogeochemistry 1, pp. 183-192.

Noël, H., Garbolino, E., Brauer, A., Lallier-Vergès, E., de Beaulieu, J.L. and Disnar, J.R., 2001. Human impact and soil erosion during the last $5000 \mathrm{yrs}$ as recorded in lacustrine sedimentary organic matter at Lac d'Annecy, the French Alps. Journal of Paleolimnology 25, pp. 229-244.

Odum, W. and Heald, E., 1975. The detritus-based food web of an estuarine mangrove community. Estuarine Research 1, pp. 265-286.

Patience, A.J., Lallier-Vergès, E., Albéric, P., Tribovillard, N.P. and Desprairies, A., 1996. Impact of early diagenesis on the organo-mineral composition of recent lacustrine sediment: Le lac du Bouchet (France). Quaternary Science Review 15, pp. 213-222.

Perrussel, B.P., Lallier-Vergès, E., Baltzer, F., Disnar, J.R. and Rivière, M., 1999. To what extent is the palaeoenvironmental signal of organic matter modified by the root-systems of living mangroves? A quantitative assessment based on an example from Guadeloupe (French West Indies). Bulletin de la Société Géologique de France 170 2, pp. 131-143.

Reeburgh, W.S., 1983. Rates of biogeochemical processes in anoxic sediments. Annual Review of Earth and Planetary Sciences 11, pp. 269-298.

Scholander, P.F., Van dam, L. and Sholander, S.I., 1955. Gas exchange in the roots of mangrove. American Journal of Botany 42, pp. 92-98.

Service Hydrographique et Océanographique de la Marine SHOM (2001). Annuaire des marées pour l'an 2002. Ports d'outre-mer.

Stout, S.A. and Spackman, W., 1987. A microscopic investigation of woody tissues in peats: some processes active in the peatification of ligno-cellulosic cell walls. International Journal of Coal Geology 8, pp. 33-54. 
Thibodeau, F.R. and Nickerson, N.H., 1986. Differential oxidation of mangrove substrate by Avicenia germinans and Rhizophora mangle. American Journal of Botany 73 4, pp. 512-516. 